\title{
Perbandingan Metode Klasifikasi Data Mining Untuk Rekomendasi Tanaman Pangan
}

\author{
Merlinda Wibowo*, Rafian Ramadhani \\ Fakultas Informatika, Program Studi Informatika, Institut Teknologi Telkom Purwokerto, Jawa Tengah, Indonesia \\ Email: ${ }^{1,{ }^{*}}$ merlinda@ittelkom-pwt.ac.id, ${ }^{1} 18102245 @$ ittelkom-pwt.ac.id \\ Email Penulis Korespondensi: merlinda@ittelkom-pwt.ac.id
}

\begin{abstract}
Abstrak-Penentuan tanaman pangan yang tepat perlu dilakukan untuk meningkatkan perekonomian masyarakat dalam bidang pertanian. Penggunaan pola tanam tradisional perlu dilakukan perubahan dengan memanfaatkan teknologi informasi. Pemanfaatan data dari pemerintah daerah dapat digunakan untuk membantu dalam memberikan rekomendasi jenis tanaman pangan dengan cara diolah dengan beberapa metode data mining. Metode ini dapat melakukan ektraksi informasi untuk menemukan pola dan pengetahuan dari data tersebut. Pendekatan metode klasifikasi digunakan sebagai pengelompokan data bedasarkan keterikatan data terhadap data sampel. Beberapa metode klasifikasi yang digunakan pada penelitian ini, yaitu Nä̈ve Bayes, Decision Tree, Support Vector Machine (SVM), Neural Network, Random Tree, Random Forest, dan K Nearest Neighbor $(K N N)$. Metode-metode tersebut berhasil dibandingkan untuk mengetahui metode mana yang terbaik sebagai metode untuk membantu merekomendasikan tanaman pangan yang tepat dan akurat berdasarkan hasil kinerja klasifikasi masingmasing metode. Random Tree terpilih sebagai metode terbaik pada hasil perbadingan kinerja ini dengan penggunaan metode diskritisasi dan normalisasi pada tahap pra pemrosesan data. Hal ini dapat dilihat berdasarkan hasil nilai Akurasi, Precision, Recall, dan F1-Score pada penggunaan diskritisasi seluruhnya sebesar $98 \%$. Sedangkan, penggunaan normalisasi menunjukkan hasil nilai Akurasi, Precision, Recall, dan F1-Score seluruhnya sebesar 99\%.
\end{abstract}

Kata Kunci: Nä̈ve Bayes; Decision Tree; Support Vector Machine; Neural Network; Random Tree; Random Forest; K Nearest Neighbor; Klasifikasi; Perbandingan Metode; Rekomendasi; Tanaman Pangan

\begin{abstract}
Determination of the right food crops needs to be done to improve the community's economy in the agricultural sector. The use of traditional cropping patterns needs to be changed by utilizing information technology. The utilization of data from local governments can be used to assist in providing recommendations for types of food crops by processing them with several data mining methods. This method can extract information to find patterns and knowledge from the data. The classification method approach is used as a grouping of data based on data attachment to sample data. This study uses several classification methods, namely Naïve Bayes, Decision Tree, Support Vector Machine (SVM), Neural Network, Random Tree, Random Forest, dan K Nearest Neighbor (KNN). These methods were successfully compared to find out which method is the best to help recommend appropriate and accurate food crops based on the results of the classification performance of each method. Random Tree was chosen as the best method for the results of this performance comparison using discretization and normalization methods at the pre-processing stage of the data. It can be seen based on the results of the Accuracy, Precision, Recall, and F1-Score values on the use of discretization of $98 \%$, respectively. Meanwhile, normalization showed that the results of the Accuracy, Precision, Recall, and F1-Score values are 99\%, respectively.
\end{abstract}

Keywords: Naïve Bayes; Decision Tree; Support Vector Machine; Neural Network; Random Tree; Random Forest; K Nearest Neighbor; Classification; Comparison; Recommendation; Food Crops

\section{PENDAHULUAN}

Negara Indonesia merupakan negara agraris dimana sebagian besar penduduknya bermata pencarian dalam bidang pertanian. Pertanian merupakan salah satu sumber perekonomian negara. Pertanian juga menjadi salah satu sektor industri yang menunjang kebutuhan pokok masyarakat seperti tanaman pangan [1]-[3]. Tanaman pangan adalah kebutuhan pokok untuk memenuhi ketercukupan nutrisi tubuh manusia (karbohidrat, protein, mineral dan vitamin) yang bermanfaat untuk keberlangsungan hidup dan Kesehatan [1]. Namun, proses penentuan tanaman pangan yang tepat masih kurang maksimal karena masih banyak petani yang menggunakan pola tanam tradisional untuk menentukan jenis tanaman yang akan ditanam [1]-[4]. Selain itu, kondisi iklim dan yang telah berubah serta naikturunnya harga pasar juga mempengaruhi produktifitas lahan pertanian karena berdampak terhadap hasil panen dari tanaman pangan tersebut [3], [5]. Oleh karena itu, diperlukan solusi untuk meningkatkan efisiensi, produktifitas, dan kinerja sistem pertanian berkelanjutan mereka dengan meminimalisir kesalahan dalam pemilihan jenis tanaman yang akan ditanam.

Berbagai penelitian telah dilakukan untuk merekomendasikan tanaman pangan dengan diuji menggunakan berbagai metode klasifikasi data mining yang berbeda [1], [3]-[6]. Berdasarkan Triscowati dan Wijayanto dari Badan Pusat Statistik (BPS) [6], pengembangan model klasifikasi tanaman pangan ini dilakukan untuk mempermudah pemantauan dan menangani kondisi pertanian di Indonesia serta melakukan prediksi tanaman pangan yang lebih akurat. Menurut Kaunang et al. [7] penggunaan metode Decision Tree dapat membantu memberikan hasil pertimbangan dalam pengambilan keputusan bagi para pemangku kepentingan petani maupun mereka yang bekerja dalam industri pengolahan tanaman pangan. Hasil keputusan dalam pengelolaan hasil tanaman pangan ini ini dipengaruhi dengan mempertimbangkan beberapa keadaan seperti curah hujan, suhu ratarata dan lama penyinaran. Namun, hasil akurasi rata-ratanya masih cukup rendah yaitu $69,48 \%$. Sehingga, peneliti menyarankan untuk melakukan investigasi selanjutnya dengan melakukan perbandingan dengan beberapa model 
yang lain dengan menambahkan parameter-parameter yang lebih banyak lagi terkait dengan faktor pertumbuhan tanaman pangan ini. Selain itu, Sianturi dan Hasibuan [5] juga menggunakan metode Decision Tree untuk melakukan prediksi dari tanaman pangan akan tetapi berfokus kepada hasil produksi dari tanaman pangan tersebut. Parameter yang digunakan adalah hasil produksi, curah hujan, hama, dan luas tanam. Namun, belum dilakukan perhitungan akurasi dari penggunaan metode klasifikasi tersebut, Yanuari et al. [4] merekomendasi jenis tanaman pangan ini menggunakan pendekatan metode pembobotan dengan mertimbangkan keadaan cuaca. Penelitian ini menggunakan parameter cuaca yang lebih banyak daripada penelitian sebelumnya seperti suhu, tekanan udara, kecepatan angin, curah hujan, dan kelembapan udara. Hasil akurasinya pada penelitian menunjukkan hasil yang lebih tinggi daripada penelitian sebelumnya, yaitu 73.33\%. Selain itu, Setiadi et al. [3] juga melakukan penelitian yang sama namun dengan menggunakan pendekatan algoritma Nä̈ve Bayes untuk membantu memberikan rekomendasi tanaman pangan yang tepat. Hasil akurasi yang diperoleh pada penelitian ini adalah sebesar 85.71\%. Penelitian ini telah melakukan penambahan parameter selain dari curah hujan, suhu rata-rata dan lama penyinaran, yaitu hasil produksi, produktifitas, luas panen, dan harga jual. Pada penelitian ini, parameter yang digunakan lebih bervariasi dan lengkap sehingga dapat diperoleh hasil akurasi lebih tinggi daripada penelitian sebelumnya. Dari uraian penelitian-penelitian sebelumnya, maka diperlukan proses identifikasi metode terbaik untuk memberikan rekomendasi tanaman pangan yang sesuai dengan pemilihan parameter yang lebih bervariasi dan sesuai dengan pertimbangan keadaan cuaca, hasil produksi dan harga jual sehingga hasil rekomendasi dapat lebih akurat dan tepat guna.

Data mining merupakan proses untuk mengesktraksi informasi yang sebelumnya tidak diketahui atau menemukan pola dari data sehingga dapat dijadikan solusi pengambilan keputusan [8]-[11]. Klasifikasi digunakan sebagai proses penyelesaian masalah dengan menggunakan metode dalam data mining untuk mengelompokkan data berdasarkan keterikatan data terhadap data sampel [12]. Namun, sebelum dilakukan penerapan dengan metode data mining yang tepat perlu dilakukan pengujian sebagai pembuktian bahwa metode yang digunakan sudah tepat dan akurat. Beberapa metode klasifikasi yang telah digunakan oleh penelitian sebelumnya dapat dibandingkan dan tentukan mana metode yang terbaik sebagai metode untuk mendukung proses pemberian rekomendasi pada tanaman pangan. Berdasarkan uraian diatas, penelitian ini melakukan perbandingan kinerja dari metode-metode klasifikasi untuk mengetahui metode mana yang menghasilkan kinerja yang terbaik. Metode-metode klasifikasi yang dipilih adalah metode yang populer digunakan untuk proses klasifikasi dan sering digunakan pada proses perbandingan metode. Penelitian ini akan menggunakan beberapa metode klasifikasi data mining, antara lain Nä̈ve Bayes, Decision Tree, SVM, Neural Network, Random Tree, Random Forest, dan KNN [8]-[11], [13]-[16]. Metode klasifikasi yang terpilih akan digunakan sebagai metode yang terbaik dalam membantu untuk penentuan hasil keputusan atau rekomendasi tanaman pangan.

\section{METODOLOGI PENELITIAN}

Dalam melakukan proses perbandingan metode klasifikasi sebagai metode mana yang terbaik dalam rekomendasi penentuan tananaman pangan perlunya untuk perancangan kerangka kerja penelitian. Kerangka kerja ini diperlukan sebagai gambaran umum untuk proses penyelesaian masalah pada proses perbandingan metode klasifikasi agar mendapatkan solusi dan hasil yang akurat, cepat dan tepat. Kerangka kerja penelitian dapat dilihat pada gambar 1 .

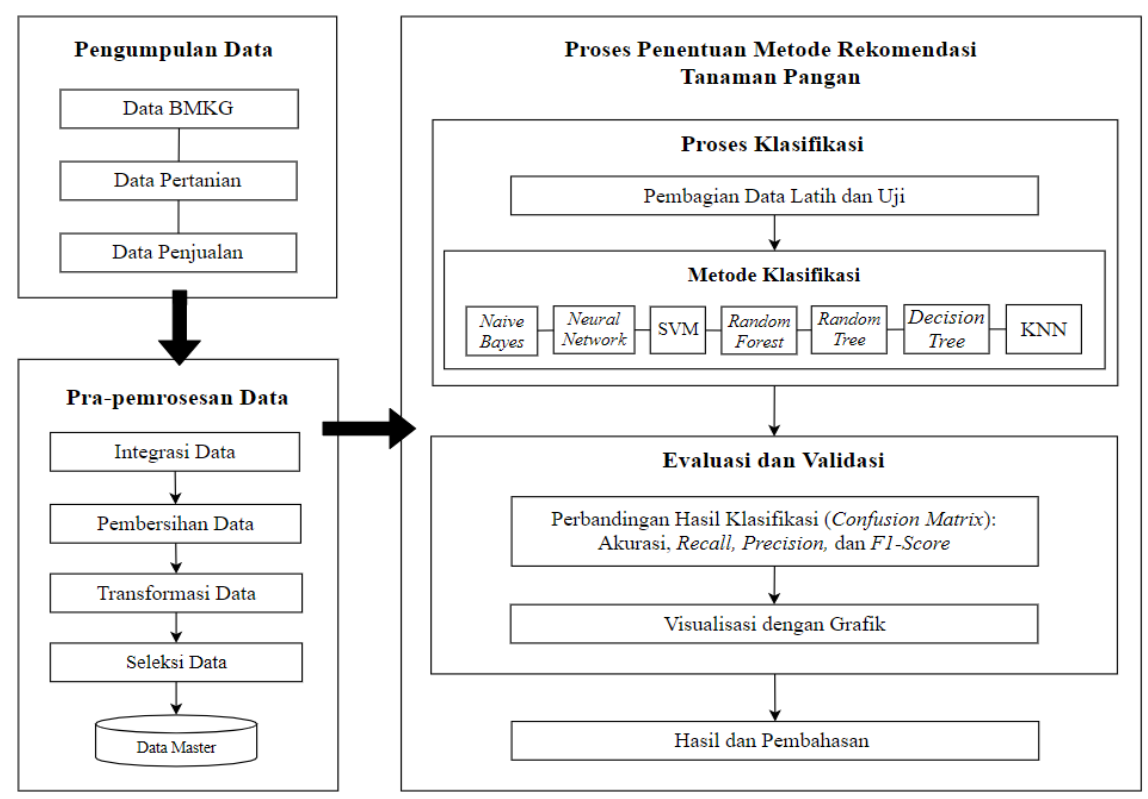

Gambar 1. Kerangka Kerja Penelitian 
ISSN 2614-5278 (media cetak), ISSN 2548-8368 (media online)

Available Online at https://ejurnal.stmik-budidarma.ac.id/index.php/mib DOI 10.30865/mib.v5i3.3086

\subsection{Pengumpulan Data}

Data yang dipakai dalam penelitian ini antara lain data cuaca dari Badan Meteorologi Klimatologi dan Geofisika (BMKG) Provinsi Daerah Istimewa Yogyakarta (DIY), data hasil panen dari Dinas Pertanian Provinsi DIY, dan harga jual hasil produksi panen dari Badan Ketahanan Pangan dan Penyuluhan (BKPP) DIY pada tahun 2015 sampai 2017. Data cuaca di dapat dari stasiun Geofisika Yogyakarta dengan beberapa parameter yaitu suhu udara, kelembapan udara, tekanan udara, kecepatan angin, lama penyinaran matahari, jumlah hari hujan, dan curah hujan. Beberapa sampel data dapat dilihat pada tabel 1 .

Tabel 1. Sampel Data Cuaca BMKG Tahun 2017

\begin{tabular}{lcccccc}
\hline Bulan & $\begin{array}{c}\text { Temperatur } \\
\text { Rata-rata }\left({ }^{\circ} \mathrm{C}\right)\end{array}$ & $\begin{array}{c}\text { Kelembapan } \\
\text { Rata-rata (\%) }\end{array}$ & $\begin{array}{c}\text { Tekanan } \\
\text { Udara } \\
(\mathrm{mb})\end{array}$ & $\begin{array}{c}\text { Lama } \\
\text { Penyinaran } \\
\text { Matahari }(\%)\end{array}$ & $\ldots$ & $\begin{array}{c}\text { Curah } \\
\text { Hujan } \\
(\mathrm{mm})\end{array}$ \\
\hline Januari & 26.0 & 88.0 & 1012.5 & 37 & $\ldots$ & 455 \\
Februari & 26.1 & 87.6 & 1013.2 & 48 & $\ldots$ & 430 \\
Maret & 26.3 & 87.0 & 1013.3 & 57 & $\ldots$ & 436 \\
$\ldots$ & $\ldots$ & $\ldots$ & $\ldots$ & $\ldots$ & $\ldots$ & $\ldots$ \\
Desember & 26.3 & 85.9 & 1012.5 & 52 & $\ldots$ & 372 \\
\hline
\end{tabular}

Pada tabel 2 disajikan sampel data produksi tanaman padi dan palawija dari Dinas Pertanian pada Tahun 2017 yang berupa data luas panen per hektar, angka produktifitas pertanian (hasil panen per hektar dalam kuintal), dan hasil produksi dalam ton. Data ini direpresentasikan dalam per empat bulanan pada setiap Kabupaten atau Kota.

Tabel 2. Sampel Data Produksi, Produktifitas dan Luas Panen Tahun 2017

\begin{tabular}{ccccccccc}
\hline \multirow{2}{*}{ No. } & \multirow{2}{*}{ Kabupaten/Kota } & \multicolumn{3}{c}{ Januari-April } & $\ldots$ & \multicolumn{3}{c}{ September-Desember } \\
& & LP & Ku/ha & Produksi & $\ldots$ & LP & Ku/ha & Produksi \\
\hline 1 & Kulonprogo & $1,268.0$ & 64.28 & 8,151 & $\ldots$ & 2,6521 & 73.60 & 19,522 \\
2 & Bantul & 212.8 & 58.63 & 1,248 & $\ldots$ & 2,813 & 93.33 & 26,255 \\
3 & Gunungkidul & $44,830.9$ & 41.06 & 184,076 & $\ldots$ & 424 & 60.41 & 2,563 \\
4 & Sleman & 333.9 & 49.20 & 1,643 & $\ldots$ & 5,961 & 78.66 & 44,765 \\
Jumlah KAB (Tanpa KOTA) & $46,645.6$ & 41.83 & 195,118 & $\ldots$ & 11,581 & 80.40 & 93,105 \\
\hline
\end{tabular}

Tabel 3 pemperlihatkan contoh data harga jual pada produsen yang tersaji dalam per minggu. Harga jual direpresentasikan dalam satuan rupiah perkilogram dalam rentang tahun 2015 hingga 2017 yang telah dihimpun oleh BKPP DIY.

Tabel 3. Sampel Data Harga Jual Daerah Bantul 2017

\begin{tabular}{|c|c|c|c|c|c|c|}
\hline Komoditas & Satuan & Minggu 1 & Minggu 2 & Minggu 3 & Minggu 4 & Rata-rata \\
\hline $\begin{array}{l}\text { Jagung Pipilan Kering Tingkat } \\
\text { Petani }\end{array}$ & $\mathrm{Rp} / \mathrm{Kg}$ & 3,400 & 3,425 & 3,450 & 3,475 & 3,438 \\
\hline $\begin{array}{l}\text { Kedelai Biji Kering Tingkat } \\
\text { Petani }\end{array}$ & $\mathrm{Rp} / \mathrm{Kg}$ & 6,725 & 6,900 & 6,950 & 6,950 & 6,881 \\
\hline$\ldots$ & $\ldots$ & $\cdots$ & $\cdots$ & $\cdots$ & $\cdots$ & $\cdots$ \\
\hline $\begin{array}{l}\text { Beras Premium Tingkat } \\
\text { Penggilingan }\end{array}$ & $\mathrm{Rp} / \mathrm{Kg}$ & 10,933 & 11,392 & 11,767 & 11,767 & 11,465 \\
\hline
\end{tabular}

\subsection{Pra Pemrosesan Data}

Pra pemrosesan data diterapkan untuk meningkatkan akurasi pada proses perbandingan metode klasifikasi pada data yang disajikan [8]-[11], [14]. Semua data yang terkumpul yang masih dalam format raw perlu diintegrasikan, dibersihkan, ditransformasikan kemudian diseleksi berdasarkan atribut-atribut datanya yang telah disesuaikan dengan kebutuhan proses komparasi metode klasifikasi ini.

\subsubsection{Integrasi Data}

Data yang telah terkumpul kemudian diintegrasikan untuk digunakan ke dalam proses selanjutnya. Data integrasikan untuk menghasilkan penyediaan informasi yang lebih akurat sebagai pengambilan keputusan, efisiensi operasional dan penciptaan solusi yang tepat [17], [18]. Data cuaca diintegrasikan dengan data hasil produksi tanaman pangan dan harga jual yang telah disesuaikan berdasarkan bulan dan tahun. Data yang dipakai adalah data yang dikolektif dari bulan januari 2015 hingga desember 2017 atau dalam jangka waktu tiga tahun. Hal ini nantinya akan digunakan sebagai dasar rekomendasi untuk tanaman pangan yang sesuai pada kebutuhan petani. 


\subsubsection{Pembersihan Data}

Setelah data berhasil dintegrasikan atau digabungkan menjadi satu kemudian data akan dibersihkan. Pembersihan data ini meliputi penghapusan duplikasi data, pengecekan data yang tidak konsisten dan perbaikan kesalahan data dengan melakukan pergantian data dengan melakukan perhitungan rata-rata untuk mengisi pada data yang kosong [14], [18], [19]. Data-data yang tidak diperlukan seperti pada data cuaca tidak semua data akan dipergunakan dalam penelitian ini. Dari berbagai atribut pada data cuaca hanya digunakan beberapa parameter yang memiliki pengaruh pada pertumbuhan tanaman pangan seperti temperature, kelembapan udara, intesitas cahaya, dan curah hujan [3]-[5], [7].

\subsubsection{Transformasi Data}

Dalam penelitian ini, tranformasi data merupakan salah satu elemen yang penting dalam pengolahan data sehingga dapat membantu dalam proses pengambilan keputusan [18]. Data ditransformasi menjadi bentuk data yang didasarkan pada tanaman pangan sebagai atribut keputusannya yang terdiri dari Padi, Jagung, Kedelai, Kacang Tanah, dan Ubi Kayu. Atribut keputusan ini disesuaikan dengan hasil komoditi pangan dari kabupaten atau kota di DIY. Kemudian, tranformasi data ini nantinya akan melewati dua proses yang akan dibandingkan juga yaitu diskritisasi dan normalisasi data. Metode ini merupakan teknik penting untuk meningkat kualitas data.

Diskritisasi data digunakan untuk mengurangi dan menyederhanakan raw data untuk meningkatkan kinerja proses klasifikasi yang lebih cepat, tepat, dan akurat. Melakukan diskretisasi pada setiap atribut dengan tipe numerik dan mengganti nilainya dengan nilai interval diskret. Pendekatan ini dilakukan dengan mentransformasikan fitur kontinu ke dalam fitur ordinal. Beberapa peneliti menggunakan metode ini untuk mereduksi data hingga mengekstraksi pola dari data [18], [20], [21]. Sedangkan normalisasi data digunakan untuk menyamakan rentang nilai pada setiap atribut dengan menggunakan skala tertentu [22], [23]. Normalisasi ini perlu dilakukan juga untuk mengoptimalkan kinerja dari metode yang digunakan pada proses klasifikasi nanti. Penggunaan normalisasi ini dapat dipastikan memiliki pengaruh yang besar terhadap performa dari hasil klasifikasi [22], [23].

\subsubsection{Seleksi Data}

Pada proses seleksi data ini, data yang digunakan pada penelitian ini sebanyak 900 baris data yang terdiri dari beberapa atribut yang digunakan sebagai penentu rekomendasi tanaman pangan. Atribut yang digunakan sebagai berikut:

a. Daerah. Kabupaten atau kota di DIY.

b. Bulan dan Tahun. Waktu dimana data dikumpulkan pada setiap bulannya pada tahun 2015-2017.

c. Curah Hujan. Rata-rata curah hujan dalam skala milimeter setiap bulan dari masing-masing kabupaten atau kota.

d. Suhu. Suhu rata-rata perbulan dari setiap kabupaten atau kota dalam skala celcius.

e. Penyinaran matahari. Lama penyinaran yang terkena sinar matahari perbulannya dari setiap kabupaten atau kota dalam skala persen.

f. Hasil Produksi. Jumlah produksi permusim dalam skala ton dari setiap kabupaten atau kota.

g. Harga. Harga setiap komoditi tanaman pangan perkilogram pada setiap kabupaten atau kota.

h. Keuntungan. Keuntungan yang diperoleh perkilogramnya dari haga jual dikurangi dengan biaya produksi.

i. Tanaman. Komoditi tanaman pangan yang ada dihasilkan dari kabupaten atau kota di DIY.

Hasil dari secara keseluruhan pra pemrosesan data secara dipresentasikan pada Tabel 4.

Tabel 4. Sampel Pra Pemrosesan Data

\begin{tabular}{|c|c|c|c|c|c|c|c|c|c|c|c|c|c|c|}
\hline Daerah & Bulan & Tahun & $\begin{array}{l}\text { Curah } \\
\text { Hujan }\end{array}$ & Suhu & $\begin{array}{c}\text { Kelem- } \\
\text { bapan }\end{array}$ & $\begin{array}{c}\text { Teka-nan } \\
\text { Uda- } \\
\text { ra }\end{array}$ & $\begin{array}{c}\text { Penyi- } \\
\text { naran } \\
\text { Mata- } \\
\text { hari }\end{array}$ & $\begin{array}{l}\text { Produk- } \\
\text { si }\end{array}$ & Harga & $\begin{array}{l}\text { Luas } \\
\text { Panen }\end{array}$ & $\begin{array}{l}\text { Produk- } \\
\text { tivitas }\end{array}$ & $\begin{array}{c}\text { Biaya } \\
\text { Produk-si }\end{array}$ & $\begin{array}{l}\text { Keun- } \\
\text { tungan }\end{array}$ & $\begin{array}{c}\text { Tanaman } \\
\text { Pangan }\end{array}$ \\
\hline $\begin{array}{l}\text { Kulon } \\
\text { Progo }\end{array}$ & Januari & 2015 & 400 & 26,2 & 85 & 1000,6 & 60 & 42810 & 4060 & 6412 & 66,77 & 1812,191 & 2247,81 & Padi \\
\hline $\begin{array}{c}\text { Bantul } \\
\text { Gunung }\end{array}$ & April & 2015 & 386 & 26,4 & 88 & 996,3 & 60 & 8776 & 2813 & 1602 & 594,555 & 203,5136 & 2609,49 & Jagung \\
\hline Kidul & Februari & 2017 & 362 & 26,1 & 87,6 & 1013,2 & 48 & 232184 & 3513 & 49139 & 8440,038 & 1,007104 & 3511,99 & Padi \\
\hline $\begin{array}{c}. \cdot \\
\text { Sleman }\end{array}$ & $\begin{array}{c}\ldots \\
\text { Mei }\end{array}$ & $\begin{array}{c}\ldots \\
2017\end{array}$ & $\begin{array}{c}\ldots \\
184\end{array}$ & $\begin{array}{c}\ldots \\
26,4\end{array}$ & $\begin{array}{c}\ldots \\
83,4\end{array}$ & $\begin{array}{c}\ldots \\
1014,1\end{array}$ & $\begin{array}{l}\ldots \\
75\end{array}$ & $\begin{array}{l}\ldots \\
22\end{array}$ & $\begin{array}{c}\ldots \\
7800\end{array}$ & $\ddot{23}$ & $\begin{array}{c}\ldots \\
13788\end{array}$ & $\begin{array}{c}\ldots \\
0,616478\end{array}$ & $\begin{array}{c}\ldots \\
7799,38\end{array}$ & $\begin{array}{c}\cdots \\
\text { Kedelai }\end{array}$ \\
\hline
\end{tabular}

\subsection{Proses Penentuan Metode Rekomendasi Tanaman Pangan}

Proses penentuan metode rekomendasi tanaman pangan mengunakan beberapa metode data mining yang dapat menemukan informasi pengetahuan yang bermanfaat dari berbagai data dengan cara mengekstrasi dan pengenalan pola penting atau menarik dari data. Beberapa metode data mining yang sering dipakai sebagai metode untuk pengklasifikasian data seperti Nä̈ve Bayes, Decision Tree, SVM, Neural Network, Random Tree, Random Forest, dan KNN [8]-[11], [13]-[16]. 


\subsubsection{Proses Klasifikasi}

Sebelum melalui proses klasifikasi, data dibagi menjadi dua bagian yaitu data latih dan data uji dengan presentase perbandingan adalah 70:30. Prosedur pembagian data ini dapat mendukung kinerja dari proses klasifikasi agar cepat dan lebih akurat [14], [19].

a. Nä̈ve Bayes

Nä̈ve Bayes merupakan salah satu metode dalam klasifikasi yang dapat menggunakan pengetahuan probabilitas dan statistik dengan menerapkan teorema Bayes dalam berbagai bidang [3], [24]-[26]. Teorema Bayes dapat digambarkan pada rumus berikut:

$$
P(H \mid E)=\frac{P(E \mid H) x P(H)}{P(E)}
$$

Dimana, $P(H \mid E)$ merupakan probabilitas akhir bersyarat suatu hipotesis $\mathrm{H}$ terjadi jika diberikan bukti $\mathrm{E}$. Sedangkan, $P(E \mid H)$ menunjukkan probabilitas sebuah bukti E terjadi akan memengaruhi hipotesis $H$. $P(H)$ adalah probabilitas awal (priori) hipotesis $\mathrm{H}$ terjadi tanpa memandang bukti apapun. Selanjutnya, $P(E)$ merupakan probabilitas awal (priori) bukti E terjadi tanpa memandang hipotesis atau bukti yang lain. Pada metode ini, diperlukan untuk mengasumsikan bentuk tertentu dari distribusi probabilitas untuk atribut numerik dan memperkirakan parameter distribusi dengan data pelatihan. Distribusi Gaussian biasanya dipilih untuk merepresentasikan probabilitas bersyarat dari fitur kontinu pada sebuah kelas $P(X i \mid Y)$, sedangkan distribusi Gaussian dikarakteristikkan dengan dua parameter yaitu mean dan varian. Pada setiap kelas $y j$, probabilitas bersyarat kelas $y j$ untuk fitur $X i$ ditunjukkan pada rumus berikut:

$$
P(X i=x i \mid Y=y i)=\frac{1}{\sqrt{2 \pi \sigma i j}} \exp -\frac{(x i-\mu i j)^{2}}{2 \sigma^{2} i j}
$$

Dimana, $P$ adalah peluang, $X i$ merupakan atribut ke I, $x i$ nilai atribut ke I, $Y$ adalah kelas yang dicari, dan $y i$ adalah sub kelas yang dicari. Kemudian, $\mu$ adalah rata-rata dari seluruh atribut dan $\sigma$ merupakn standar deviasi pada varian dari seluruh atribut. Hal ini menunjukkan bahwa Naïve Bayes harus menggunakan semua atribut dalam data yang kemudian masing-masing akan dianalisis untuk menunjukkan pentingnya independensi setiap atribut [24]-[26].

b. Decision Tree

Decision Tree menggunakan grafik seperti pohon dan bertindak sebagai sistem pendukung keputusan. Metode ini telah berhasil diimplementasikan sebagai metode untuk melakukan klasifikasi pada tanaman pangan [1], [5]. Dalam metode ini, simpul internal akan menunjukkan pengujian pada atribut, cabang akan menandakan hasil pengujian, dan simpul daun menunjukkan label kelas. Pada pemilihan atribut dengan akar perlu adanya penentuan niai gain tertinggi dari atribut-atribut yang ada. Gain merupakan salah satu atribut seleksi ukuran yang digunakan untuk memilih atribut tes pada setiap node pada pohon [5]. Berikut rumus yang dapat digunakan untuk memilih atribut tersebut yang ditunjukkan pada rumus dibawah ini.

$$
\operatorname{Gain}(S \mid A)=\operatorname{Entropy}(S)-\sum_{i=1}^{n} \frac{\left|S_{i}\right|}{|S|} * \operatorname{Entropy}(S)
$$

Dimana, $S$ merupakan himpunan kasus, $A$ adalah atribut, dan n merupakan jumlah partisi atribut $A$. Sedangkan, $\left|S_{i}\right|$ menunjukkan jumlah kasus pada partisi ke I dan $|S|$ jumlah kasus dalam $S$. Selain itu, untuk menghitung nilai entropi dapat dilihat pada rumus dibawah ini.

$\operatorname{Entropy}(S)=\sum_{i=1}^{n}-p i * \log _{2} p i$

Dimana, $S$ merupakan himpunan kasus, $A$ adalah atribut, dan n merupakan jumlah partisi $S$. Sedangkan, $p i$ menunjukkan proporsi dari $S_{i}$ terhadap $S$.

c. Support Vector Machine (SVM)

SVM adalah salah satu metode klasifikasi yang mempunyai prinsip dasar linier classifier (kasus klasifikasi yang secara linier dapat dipisahkan). Namun, penambahan konsep kernel pada tempat kerja berdimensi tinggi dapat membantu dalam memecahkan masalah non-linier. Kernel dapat diartikan sebagai suatu fungsi yang memetakan ulang data pada ruang dimensi asal ke dalam ruang dimensi yang lebih baru untuk sementara. Metode ini termasuk metode yang sering dipakai untuk melakukan penentuan keputusan hingga proses prediksi dengan tingkat akurasi yang cukup tinggi [11]-[13], [15]. Metode ini akan memisahkan ruang atribut dengan hyperplane untuk memaksimalkan margin antara instance dari suatu kelas dengan nilai kelasnya [11], [27]. Efisiensi algoritma ini tidak terlihat secara akan tetapi tergantung pada dimensi entitas yang diklasifikasikan secara akurat dan paling kuat daripada metode lainnya. 


\section{d. Neural Network}

Metode ini telah digunakan beberapa peneliti sebagai salah satu metode untuk klasifikasi [6], [8], [11]. Metode ini akan meniru fungsi otak manusia yang didalamnya terdapat ribuan bahkan jutaan jaringan neuron. Neuron merupakan unit pengolahan kecil yang saling terhubung satu sama lainnya dan memiliki input dan keluaran [8]. Metode ini dapat memodelkan hubungan yang kompleks antara input dan output untuk mendapatkan pola dari datanya dan mampu memecahkan suatu masalah berdasarkan hasil informasi yang berasal dari eksternal maupun internal pada jaringan neuron tersebut [15]

e. Random Tree

Random Tree mempelajari tentang pohon keputusan dan menggunakan subset acak untuk setiap pemisahan dari atribut yang tersedia. Metode ini terdiri dari dua tahapan, pertama metode ini dapat membangun pohon keputusan menggunakan sebagian data sebagai data latih dan memilih fitur untuk memotong nilai yang memaksimalkan perolehan informasi dengan persyaratan pada setiap tahapnya [14]. Struktur yang dihasilkan atau disebut dengan kerangka pohon, akan berulang sampai pohon mencapai target yang telah ditentukan. Kedua, data latih digunakan untuk menentukan nilai atau klasifikasi yang sesuai dengan melakukan perhitungan statistik kelas pada node daun. Fitur dari data pelatihan digunakan untuk membangun struktur pohon dan data itu sendiri untuk memperbarui probabilitas kelas. Probabilitas ini digunakan untuk melacak jumlah sampel yang diklasifikasikan oleh setiap node. Pada titik uji, setiap pohon menghasilkan probabilitas kelas. Probabilitas dari semua pohon dalam ensemble dirata-ratakan untuk menghasilkan estimasi probabilitas kelas secara keseluruhan [12], [28]. Metode ini mudah untuk diterapkan dan juga dapat menghasilkan hasil prediksi yang maksimal karena representasi data dalam bentuk pohon akan memiliki keunggulan dibandingkan dengan pendekatan lainnya [12], [28].

f. Random Forest

Random Forest digunakan dalam klasifikasi, regresi dan tugas lainnya berdasarkan metode ensamble dalam hal pembelajaran data. Kinerja pada metode ini diadaptasi dari metode decision tree yang setiap pohonnya dikempakan dari sampel bootstrap pada data latih. Nantinya subset dari atribut diambil secara acak dari atribut terbaiknya dengan dilakukan pemilihan secara dibagi menjadi dua bagian [6], [12], [28]. Metode ini akan menciptakan contoh acak dari informasi dan susunan kunci ascribe untuk mengembangkan pohon pilihan. Proses klasifikasi akan dibuat untuk data yang tidak teramati dengan mengambil suara mayoritas dari masingmasing pohon. Hal ini dapat memberikan hasil kinerja yang maksimal dalam berbagai masalah fungsional terutama dalam pengumpulan informasi yang tidak bertanggung jawab pada overfitting. Oleh karena itu, penggabungan klasifikasi dari beberapa pohon masing-masing perlu dilatih secara terpisah. Selain itu, metode ini dapat mengatasi noise dan outlier dengan baik dan dapat dengan mudah diimplementasikan.

g. KNearest Neighbor $(K N N)$

KNN merupakan metode yang paling sederhana untuk dipahami dan mudah untuk diimplementasikan sehingga beberapa penelitian telah menerapkan metode untuk proses klasifikasi [2], [8], [11], [12], [26], seperti pada penentuan produktifitas tanaman pertanian [29]. Metode ini menerapkan pemilihan nilai yang sesuai untuk k, yaitu jumlah data yang terdekat dengan suatu obyek. Proses klasifikasi akan bergantung kepada nilai k tersebut. Sehingga untuk memilih nilai k ini, metode ini harus dijalankan berulang kali untuk dapat menghasilkan nilai $\mathrm{k}$ yang berbeda-beda dan kemudian diambil nilai yang memiliki kinerja terbaik [26]. Persamaan yang memenuhi metode KKN ini dapat dilihat pada rumus berikut ini:

$$
d\left(x_{i}, x_{j}\right)=\sqrt{\sum_{r=1}^{n}\left(a_{r}\left(x_{i}\right)-a_{r}\left(x_{j}\right)\right)^{2}}
$$

Dimana, hasil dari adalah pengurangan pada masing-masing atribut yang dikuadratkan dan akan dijumlahkan berdasarkan nilai yang kecil dengan menggunakan data uji.

\subsubsection{Evaluasi dan Validasi}

Pada tahap evaluasi dan validasi ini akan meliputi perbandingan hasil klasifikasi dan visualisasi data dalam bentuk grafik. Hasil dari proses klasifikasi dari beberapa metode yang dipakai seperti Nä̈ve Bayes, Decision Tree, SVM, Neural Network, Random Tree, Random Forest, dan KNN; dilakukan untuk memilih metode mana yang terbaik sebagai metode dalam penentuan tanaman pangan. Confusion Matrix merupakan metode dalam evaluasi yang dapat menentukan kinerja yang tepat pada sebuah klasifikasi yang berdasarkan pada Akurasi, Recall, Precision, dan F1-Score [14], [19], [26].

Akurasi akan menjelaskan tingkat efektifitas dari metode yang digunakan pada proses klasifikasi. Recall nantinya akan menunjukkan padanan rasio prediksi benar positif dengan keseluruhan jumlah data yang benar positif. Sedangkan, Precision menunjukkan padanan dari rasio prediksi benar positif dengan keseluruhan hasil yang diprediksi positif. F1-score kemudian akan melakukan perhitungan dengan membandingkan rata-rata nilai Recall dan Precision yang dibobotkan [14], [19], [26]. Perhitungan dari akurasi, Recall, Precision, dan F1-Score tersebut dapat dilihat pada rumus berikut ini. 
Dimana $T N$ (True Negative) adalah jumlah data negatif yang terdeteksi dengan benar, sedangkan, FP (False Positive) adalah data negative tetapi teridentifikasi sebagai data positif. TP (True Positive) merupakan data positif yang terdeteksi dengan benar dan $F N$ (False Negative) adalah data positif tetapi diidentifikasi sebagai data negative, kebalikan dari FP. Selain hasil perhitungan confusion matrix, visualisasi hasil klasifikasi dalam bentuk grafik perlu dilakukan untuk mempermudah pembacaan hasil dari klasifikasi [30]. Setiap hasil kinerja nantinya dapat didokumentasikan dengan baik sebagai repesentasi untuk pemilihan metode yang tepat dan akurat.

\section{HASIL DAN PEMBAHASAN}

Kinerja pada penggunaan metode klasifikasi perlu dilakukan perbandingan untuk dapat ditentukan metode mana yang tepat berdasarkan kualitas dan efektifitas dari hasil evaluasi dan validasi yang telah dilakukan. Langkah ini diperlukan untuk menetukan metode mana yang terbaik sebagai metode yang dapat mendukung proses penentuan tanaman pangan atau memberikan rekomendasi yang akurat dan tepat guna. Hal ini dapat dijadikan sebagai dasar dari penelitian yang dapat dilanjutkan ke tahapan untuk diimplementasikan secara langsung ke dalam bidang pertanian. Rekomendasi tanaman pangan ini tentunya sangat membantu pada petani saat ini yang dapat berpengaruh juga dalam perekonomian bangsa ini.

Rekomendasi ini sangat dibutuhkan pada era perubahan iklim yang sulit untuk diprediksi lagi. Selain itu, cara yang dilakukan secara turun menurun dapat dihindari dengan mengubahnya menjadi lebih moderen dengan menerapkan teknologi sebagai pemberi informasi. Peningkatan perekonomian petani bangsa ini dapat diketahui dari keuntungan yang didapat dari hasil panen yang dijual dengan harga yang sedang tinggi. Sehingga penentuan metode yang tepat perlu dilakukan berdasarkan dari atribut-atribut yang terpilih. Data yang telah melewati pra pemrosesan data kemudian diproses kembali untuk memperoleh hasil confusion matrix. Hasil ini digunakan sebagai acuan untuk melakukan perbandingan kinerja masing-masing metode klasifikasi.

Metode klasifikasi yang berhasil dibandingkan pada penelitian ini meliputi Nä̈ve Bayes, Decision Tree, SVM, Neural Network, Random Tree, Random Forest, dan KNN. Berdasarkan hasil pengujian dengan mengunakan bahasa pemrograman python dengan aplikasi jupyter notebook, didapat tabel perbandingan perfoma dari masingmasing metode. Perbandingan kinerja ini dibagi menjadi dua bentuk transformasi data yaitu dengan diskritisasi dan normalisasi. Perbandingan kinerja ini masing-masing menghasilkan nilai Akurasi, Recall, Precision, dan F1Score. Perbandingan dengan penggunaan disktritisasi ditunjukkan pada Tabel 5 dan penggunaan normalisasi pada tabel 6.

Tabel 5. Hasil Kinerja Klasifikasi dengan Diskritisasi

\begin{tabular}{lcccc}
\hline \multicolumn{1}{c}{ Metode } & Akurasi (\%) & Precision (\%) & Recall (\%) & F1-Score (\%) \\
\hline Nä̈ve Bayes & 94 & 96 & 94 & 95 \\
Decision Tree & 97 & 98 & 97 & 97 \\
SVM & 97 & 97 & 97 & 97 \\
Neural Network & 97 & 97 & 97 & 97 \\
Random Tree & 98 & 98 & 98 & 98 \\
Random Forest & 93 & 93 & 93 & 93 \\
KNN & 82 & 84 & 83 & 83 \\
\hline
\end{tabular}

Tabel 6. Hasil Kinerja Klasifikasi dengan Normalisasi

\begin{tabular}{lcccc}
\hline \multicolumn{1}{c}{ Metode } & Akurasi (\%) & Precision $(\%)$ & Recall $(\%)$ & F1-Score (\%) \\
\hline Nä̈ve Bayes & 81 & 83 & 82 & 82 \\
Decision Tree & 98 & 98 & 98 & 98 \\
SVM & 84 & 85 & 85 & 85 \\
Neural Network & 87 & 88 & 88 & 88 \\
Random Tree & 99 & 99 & 99 & 99 \\
Random Forest & 96 & 96 & 96 & 96 \\
KNN & 61 & 66 & 64 & 64 \\
\hline
\end{tabular}


Dari Tabel 5 dan 6, dapat diketahui bahwa penggunaan diskritisasi pada pra pemrosesan data dari beberapa metode menunjukkan hasil kinerja yang lebih tinggi daripada dengan menggunakan normalisasi. Hal ini dapat dilihat pada metode SVM, Neural Network, dan KNN yang menunjukkan bahwa penggunaan metode distritisasi ini pada pra pemrosesan data memberikan pengaruh yang signifikan pada hasil Akurasi, Precision, Recall, dan F1-Score. Hasil kinerja metode klasifikasi terbaik dilakukan dengan menggunakan metode Random Tree dengan menunjukkan tingkat akurasi mencapai $98 \%$ dengan penggunaan diskritisasi dan 99\% dengan menggunakan normalisasi. Selanjutnya, nilai Precision, Recall, dan F1-Score tertinggi juga ditunjukkan oleh metode Random Tree dengan nilai 98\% seluruhnya pada penggunaan diskritisasi dan 99\% seluruhnya dengan penggunaan normalisasi pada pra pemrosesan datanya. Visualisasi hasil klasifikasi pada tingkat akurasi kinerja dari metode yang digunakan dapat dilihat pada gambar 2 dan gambar 3.

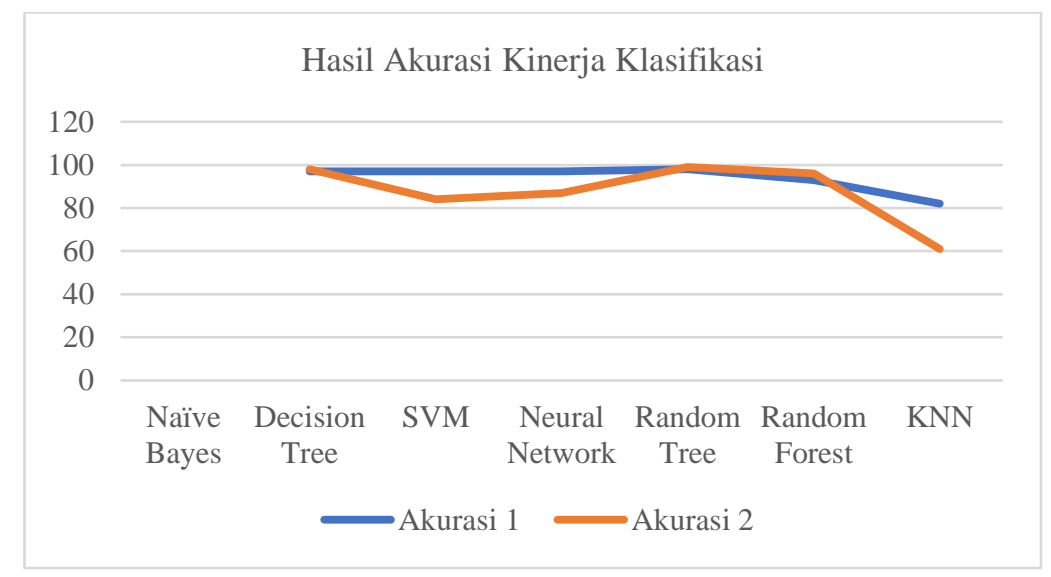

Gambar 2. Perbandingan Hasil Akurasi Kinerja Klasifikasi

Pada gambar 2 akurasi pertama menunjukkan hasil dari penggunaan diskritasi pada pra prosesan data dan akurasi kedua menunjukkan hasil dari penggunaan normalisasi. Dapat dilihat pada grafik diatas bahwa kurva penggunaan diskritasi menunjukkan hasil yang lebih signifikan daripada penggunaan normalisasi pada pra pemrosesan data. Dari hasil perbandingan metode diatas, dapat diketahui bahwa Random Tree terpilih sebagai metode terbaik sebagai metode dalam rekomendasi tanaman pangan di DIY. Hal ini dibuktikan dengan nilai Akurasi, Precision, Recall, dan F1-Score yang lebih tinggi dari metode-metode klasifikasi lainnya yang digunakan pada penelitian ini.

\section{KESIMPULAN}

Penelitian ini berhasil melakukan perbandingan hasil kinerja dari metode-metode untuk klasifikasi data. Metodemetode yang digunakan pada penelitian ini antara lain Nä̈ve Bayes, Decision Tree, SVM, Neural Network, Random Tree, Random Forest, dan KNN. Metode-metode ini melakukan klasifikasi pada data tanaman pangan di DIY untuk memberikan rekomendasi kepada petani berdasarkan atribut-atribut yang telah terpilih. Hasil rekomendasi ini dapat membantu dalam peningkatan perekonomian masyakarat khususnya dalam bidang pertanian dengan pemanfaatan teknologi sebagai pemberi informasi misalnya dalam hal keuntungan yang akan dapat dihasilkan dari hasil hasil panen dengan harga jual yang tertinggi. Apalagi dalam masa pandemi dan perubahan iklim yang tidak dapat diprediksi lagi. Berdasarkan hasil pengujian yang telah dilakukan dapat diketahui bahwa Random Tree merupakan metode terbaik yang dapat diimplementasikan sebagai metode untuk rekomendasi tanaman pangan. Hal ini ditunjukkan dengan nilai Akurasi, Precision, Recall, dan F1-Score yang lebih tinggi dari metode-metode klasifikasi lainnya dengan hasil mencapai $98 \%$ secara keseluruhan dengan penggunaan metode normalisasi dan $99 \%$ secara keseluruhan dengan penggunaan metode diskritisasi. Metode yang terpilih dapat digunakan sebagai metode untuk membantu menentukan tanaman pangan atau hasil rekomendasi yang dapat langsung diimplementasikan kepada masyakarat dalam bentuk aplikasi atau sistem.

\section{REFERENCES}

[1] F. J. Kaunang, R. Rotikan, and G. S. Tulung, "Pemodelan Sistem Prediksi Tanaman Pangan Menggunakan Algoritma Decision Tree," Cogito Smart Journal, vol. 4, no. 1. pp. 213-218, 2018.

[2] S. Maesaroh and Kusrini, "Sistem Prediksi Produktifitas Pertanian Padi Menggunakan Data Mining," Energy, J. Ilm. Ilmu-ilmu Tek., vol. 7, no. 2, pp. 25-30, 2017.

[3] T. Setiadi, F. Noviyanto, H. Hardianto, A. Tarmuji, A. Fadlil, and M. Wibowo, "Implementation Of Naïve Bayes Method In Food Crops Planting Recommendation,” Int. J. Sci. Technol. Res., vol. 9, no. 02, pp. 4750-4755, 2020.

[4] Y. Yanuari, M. G. Husada, and D. B. Utami, "Aplikasi Rekomendasi Jenis Tanaman Pangan Menggunakan Metode Simple Additive Weighting (SAW," JOINTECS (Journal Inf. Technol. Comput. Sci., vol. 3, no. 1, 2018.

[5] S. M. S. Sianturi and N. A. Hasibuan, "ANALISA DATA PERTANIAN TANAMAN PANGAN UNTUK MEMPREDIKSI HASIL PANEN DENGAN DATA MINING PANGAN dan HOLTIKUTURA PROVINSI SUMUT ),” J. Pelita Inform., vol. 18, no. April, pp. 212-219, 2019. 
[6] D. W. Triscowati and S. Indonesia, "PELUANG DAN TANTANGAN DALAM PEMANFAATAN TEKNOLOGI PENGINDERAAN JAUH DAN MACHINE LEARNING UNTUK PREDIKSI DATA TANAMAN PANGAN YANG LEBIH AKURAT," Semin. Nas. Off. Stat. 2019, no. October, 2019

[7] F. J. Kaunang, R. Rotikan, and G. S. Tulung, "Pemodelan Sistem Prediksi Tanaman Pangan Menggunakan Algoritma Decision Tree," CogITo Smart J., vol. 4, no. 1, p. 213, 2018.

[8] A. Rohman and M. Rochcham, "Komparasi Metode Klasifikasi Data Mining Untuk Prediksi Kelulusan Mahasiswa," Neo Tek., vol. 5, no. 1 , pp. 23-29, 2019

[9] W. D. Septiani, "KOMPARASI METODE KLASIFIKASI DATA MINING ALGORITMA C4.5 DAN NAIVE BAYES UNTUK PREDIKSI PENYAKIT HEPATITIS,” J. Pilar Nusa Mandiri, vol. 13, no. 1, pp. 76-84, 2017.

[10] D. P. Utomo and M. Mesran, “Analisis Komparasi Metode Klasifikasi Data Mining dan Reduksi Atribut Pada Data Set Penyakit Jantung," J. Media Inform. Budidarma, vol. 4, no. 2, p. 437, 2020

[11] T. Mardiana, H. Syahreva, and T. Tuslaela, "Komparasi Metode Klasifikasi Pada Analisis Sentimen Usaha Waralaba Berdasarkan Data Twitter," J. Pilar Nusa Mandiri, vol. 15, no. 2, pp. 267-274, 2019.

[12] I. Oktanisa and A. A. Supianto, "Perbandingan Teknik Klasifikasi Dalam Data Mining Untuk Bank a Comparison of Classification Techniques in Data Mining for,” Teknol. Inf. dan Ilmu Komput., vol. 5, no. 5, pp. 567-576, 2018.

[13] M. Ustuner, M. T. Esetlili, F. B. Sanli, S. Abdikan, and Y. Kurucu, "Comparison of crop classification methods for the sustainable agriculture management," J. Environ. Prot. Ecol., vol. 17, no. 2, pp. 648-655, 2016.

[14] M. Wibowo, S. Sulaiman, and S. M. Shamsuddin, "Comparison of Prediction Methods for Air Pollution Data in Malaysia and Singapore," Int. J. Innov. Comput., vol. 8, no. 3, pp. 65-71, 2018.

[15] Derisma and F. Febrian, "Perbandingan Teknik Klasifikasi Neural Network , Support Vector Machine , dan Naive Bayes dalam Mendeteksi Kanker Payudara,” Bina Insa. ICT J., vol. 7, no. 1, pp. 53-62, 2020

[16] Hijrah, M. Mukhlizar, and T. M. A. Pandria, "Perbandingan Teknik Klasifikasi Untuk Memprediksi Kualitas Kinerja Karyawan," J. Optim., vol. 6, no. 1, pp. 10-21, 2020.

[17] M. Wibowo, S. Sulaiman, and S. M. Shamsuddin, "Machine Learning in Data Lake for Combining Data Silos," Data Min. Big Data, vol. 10387, pp. 294-306, 2017.

[18] M. Wibowo, F. Noviyanto, S. Sulaiman, and S. M. Shamsuddin, "Machine Learning Technique For Enhancing Classification Performance In Data Summarization Using Rough Set And Genetic Algorithm," Int. J. Sci. Technol. Res., vol. 8, no. 10, pp. 1108-1119, 2019.

[19] H. Yuliansyah, R. Adi, P. Imaniati, and M. Wibowo, "Predicting Students Graduate on Time Using C4 . 5 Algorithm," J. Inf. Syst. Eng. Bus. Intell., vol. 7, no. 1, pp. 67-73, 2021.

[20] R. Bello and R. Falcon, Rough sets in machine learning: A review, vol. 708, no. Ml. 2017.

[21] Y. Kim, W. Ahn, K. J. Oh, and D. Enke, "An intelligent hybrid trading system for discovering trading rules for the futures market using rough sets and genetic algorithms," Appl. Soft Comput., vol. 55, pp. 127-140, 2017.

[22] D. A. Nasution, H. H. Khotimah, and N. Chamidah, "Perbandingan Normalisasi Data untuk Klasifikasi Wine Menggunakan Algoritma K-NN," Comput. Eng. Sci. Syst. J., vol. 4, no. 1, p. 78, 2019.

[23] A. Ambarwari, Q. J. Adrian, and Y. Herdiyeni, “Analisis Pengaruh Data Scaling Terhadap Performa Algoritme Machine Learning untuk Identifikasi Tanaman,” J. Rekayasa Sist. dan Teknol. Inf., vol. 4, no. 1, pp. 117-112, 2020.

[24] L. Jiang, C. Li, S. Wang, and L. Zhang, "Deep feature weighting for naive Bayes and its application to text classification," Eng. Appl. Artif. Intell., vol. 52, pp. 26-39, 2016.

[25] H. Zhang, Z.-X. Cao, M. Li, Y.-Z. Li, and C. Peng, "Novel naïve Bayes classification models for predicting the carcinogenicity of chemicals," Food Chem. Toxicol., vol. 97, pp. 141-149, 2016.

[26] S. T. Rizaldi and M. Mustakim, "Perbandingan Teknik Pembagian Data untuk Klasifikasi Sarana Akses Air pada Algoritma K- Nearest Neighbor dan Naïve Bayes Classifier,” Semin. Nas. Teknol. Informasi, Komun. dan Ind. 12, pp. 130-137, 2020.

[27] O. R. Indriani, E. J. Kusuma, C. A. Sari, E. H. Rachmawanto, and D. R. I. M. Setiadi, "Tomatoes classification using K-NN based on GLCM and HSV color space,” Proc. - 2017 Int. Conf. Innov. Creat. Inf. Technol. Comput. Intell. IoT, ICITech 2017, vol. 2018-Janua, pp. 1-6, 2018

[28] J. Bofana et al., "Comparison of different cropland classification methods under diversified agroecological conditions in the Zambezi River Basin," Remote Sens., vol. 12, no. 13, 2020.

[29] S. Pudumalar and E. Ramanujam, "Crop Recommendation System for Precision Agriculture," IEEE Eighth Int. Conf. Adv. Comput. Crop, pp. 32-36, 2016.

[30] M. Wibowo, S. Sulaiman, S. Mariyam, and H. Hashim, "Mobile Analytics Database Summarization Using Rough Set," Int. J. Innov. Comput., vol. 7, no. 2, pp. 6-12, 2017. 